Nig. J. Biotech. Vol. 34 (2017) 65-70

ISSN: 01891731

Available online at

http://www.ajol.info/index.php/njb/index

and www.biotechsocietynigeria.org

DOI: https://dx.doi.org/10.4314/njb.v34i1.9

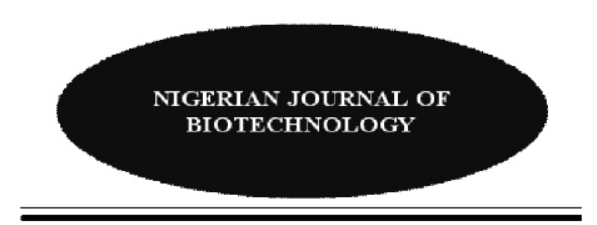

\title{
Cellulase production by Proteus spp. JC402 from plantain fruits stalk biomass using submerged fermentation
}

\author{
*Osho M. B., Aruoture, A. O. and Abatan, T. A. \\ Department of Biological Sciences, College of Natural \& Applied Sciences, McPherson University, \\ SerikiSotayo, P.M.B. 2094, Sapon, Abeokuta, Ogun State, Nigeria. \\ Copyright resides with the authors in terms of the Creative Commons License. 4.0. \\ See http://creativecommons.org/licenses/by/4.0/ \\ Condition of use: The user may copy, distribute, transmit and adapt the work, but must recognize the authors \\ and the Nigerian Journal of Biotechnology.
}

\begin{abstract}
Biodegradation of lignocellulosic biomass into a variety of value - added products (monomeric sugars) by the action of cellulolytic enzymes has recorded a significant value for industrial processes. This present work aimed at isolating and screening bacteria of soil origin capable of producing extracellular cellulase, and investigated hydrolysis of plantain fruit stalk biomass (PFSB) using submerged fermentation. Alkaline pretreated and untreated PFSB substrates were used for the cellulase production. Enzyme extract was assayed using carboxyl methyl cellulose assay method. Out of eight bacteria species screened for cellulase producing potential, four showed positive on screening medium indicated by clear or halo zone around growing microbial colonies. Proteus spp. JC402 was selected based on highest zone of inhibition $(23 \mathrm{~mm})$ on screening medium and $100 \%$ hydrolysis efficiency. Cellulase activity of pretreated PFSB $7.5 \%(\mathrm{w} / \mathrm{v})$ substrates has the highest activity $3.2 \pm 0.14 \mathrm{Uml}^{-1}$ and untreated PFSB $2 \%(\mathrm{w} / \mathrm{v})$ has $2.76 \pm 0.31$ $\mathrm{Uml}^{-1}$ at $48 \mathrm{~h}$. Cheap, unexploited, renewable and readily available agricultural cellulosic biomass has been effectively utilized for the production of a thermo stable enzyme as criteria for industrial application and environmental implications.
\end{abstract}

*Corresponding Author: +2348032698955, osho_michael@rocketmail.com

\section{Introduction}

Plants are considered as one of the most important sources of renewable biological carbon and low cost energy on the earth from which $4 \times 10^{9}$ tons of cellulose were produced annually. It can be exploited as valuable source of carbon for production of value-added chemicals (Nowak et al., 2005; Saranra et al., 2012). Cellulose is basic structural component of plant biomass and many forms of algae. Multicomplexity of genetically engineered bacteria provides increased synergy and function ability of cellulases hydrolysis efficiency. Endo-1,4- $\beta$-Dglucanase- (E.C.3.2.1.4), Exo-1,4-beta-Dglucanase (E.C.3.2.1.91) and $\beta$-glucosidase (E.C.3.2.1.21) were various type of cellulase enzymes, among which endocellulases are more active against the amorphous regions of cellulose while exocellulases are active on crystalline cellulose and cleave disaccharide units either from non-reducing or reducing end but $\beta$-Glucosidases cleave cellobiose and other soluble oligosaccharides to glucose (Bhat and Bhat, 1997).

The plantain (Musa paradisiaca) and banana (Musa sapientum) pseudostem wastes are abundant and widely available as a lignocellulosic material. Maloney (1978) stated that lignocellulosic materials are the most abundant polymers on earth which are obtainable as the original biomass. Ease of procedural handling and greater control of environmental factors such as $\mathrm{pH}$ and temperature have made submerged fermentation $(\mathrm{SmF})$ to be a conventional process 
for production of industrially significant enzymes. Lignocellulosic materials are mainly constituted from three natural polymers namely: cellulose, lignin and hemicelluloses in varying proportions depending upon the specific plant in which they occur (Casey, 1980). There are several studies on the use of agro industrial residues for the production of cellulase such includes wheat straw, baggase, cotton waste, wheat bran, flower stalks-vegetable waste and rice straw as substrates (Milala et al., 2005; Lu et al., 2006; Kumar et al., 2009; Reddy et al., 2015).

The isolation and characterization of cellulase producing bacteria and its uses in the production of cellulase via submerged fermentation using this agro industrial waste, plantain fruit stalk will help reduce the problem of soil pollution posed by indiscriminate dumping and treatment of these agricultural wastes. The enzymatic hydrolysis of cellullosic material will undoubtedly serve as a means to increase the yields of fermentable sugars available for bio-ethanol production hence making its cost effective and renewable. Application of this extracellular cellulase will improve industrial processes because of the stability properties that would be conferred on the enzymes.

\section{Materials and Methods}

Microorganisms and Substrates

Composite soil samples were obtained in sterile polythene plastic bags from Akuro Sawmill located in Sapade, Remo North Local Government Area, Ogun State, Nigeria. Isolation was done via serial dilution and pour plating and sub-culturing was done on Nutrient Agar (NA) incubated at $37^{\circ} \mathrm{C}$ for $24 \mathrm{~h}$. Pure cultures obtained were preserved on NA slants at $4^{\circ} \mathrm{C}$. Plantain fruit stalk biomass was obtained from McPherson University farm, SerikiSotayo, Nigeria and authenticated by plant physiologist.

Isolation and screening of bacteria for cellulase producing potential

Pure culture of bacteria isolates were individually inoculated into NA with $1.5 \%$ of carboxyl methyl cellulose (CMC) in agar plates and incubated at $37^{\circ} \mathrm{C}$ for $24 \mathrm{~h}$ (Olabiwoninu and Fasiku, 2015). The plates were flooded with $5 \mathrm{ml}$ Grams iodine and allow staying for 5 mins and visualized for cellulase activity. This solution stained the agar containing CMC brown and leaves areas without CMC clear describe as clear zones. Clear zone which appeared around growing bacteria colonies indicated cellulase hydrolysis (Mirands et al., 2011). The zones of hydrolysis were measured and the bacterium colony with the largest clear zone was selected for molecular identification.

\section{Determination Hydrolysis of Isolates}

Isolates was re-plated on cellulase screening medium and their halo diameter ( $\mathrm{Z}$ ) and colony diameter (C) was measured after $24 \mathrm{~h}$ of incubation at $37{ }^{\circ} \mathrm{C}$. Percentage hydrolysis efficiency of the isolates was calculated according to the method of Sreedevi and Reddy, (2012).

\section{Molecular Characterization of Bacteria Isolates}

The extraction of total genomic DNA and Polymerase Chain Reaction (PCR) using standard methods and DNA sequencing were carried out at the Bioscience Laboratory, International Institute of Tropical Research, (IITA), Ibadan, Nigeria. The obtained sequences of 16sRNA were aligned by submitting them to the nonreductant nucleotide database at Genbank using $\mathrm{th}$ e B L A S T progra m (http://www.ncbi.nlm.nch.gov) in order to determine the identity of the isolate.

Preparation and Pretreatment of Cellulose Plantain Fruit Stalk Biomass (PFSB)

The plantain (Musa paradisiaca) stalk biomass modified method of Correia et al., (2013). The enzyme assay was carried out using CMC assaycollected was sliced and oven dried at $80^{\circ} \mathrm{C}$ to constant weight using a hot air oven. The biomass was mechanically grounded with electric blender and sieved using a mesh of pour size 300 um and then stored in an air tight container for further use. 


\section{Preparation of production medium}

The basal medium was prepared according to Akpan et al. (1996) with various percentage of plantain fruit stalk biomass as follows: 2, 5 and $7.5 \%(\mathrm{w} / \mathrm{v})$ in $250 \mathrm{ml}$ conical flask containing distilled water respectively and the pretreatment slurry of the substrate was prepared by adding milled PFSB at a solid loading of 2, 5 and $7.5 \%$ $(\mathrm{w} / \mathrm{v})$ in $1 \mathrm{~N}$ sodium hydroxide solution respectively were sterilized at $121^{\circ} \mathrm{C}$ for 15 mins. The pretreated slurries were washed five times with $20 \mathrm{ml}$ each of distilled water to remove alkaline traces according to the modified method of Abraham et al., (2014). They were filtered to remove solids. To the clarified filtrates (basal medium), $\mathrm{KH}_{2} \mathrm{PO}_{4}, 0.1 \%(\mathrm{w} / \mathrm{v}) ; \mathrm{MgSO}_{4} .7 \mathrm{H}_{2} \mathrm{O}$, $0.05 \%(\mathrm{w} / \mathrm{v})$ and $\mathrm{CaCl}_{2} 2 \mathrm{H}_{2} \mathrm{O}, 0.4 \%(\mathrm{w} / \mathrm{v})$ were added to form the growth medium. The production medium consisted of growth medium plus soya beans flour $(0.5 \% \mathrm{w} / \mathrm{v})$ and soluble starch $2 \%(\mathrm{w} / \mathrm{v})$ adjusted to $\mathrm{pH} 4.0$ and autoclaved at $121^{\circ} \mathrm{C}$ for $15 \mathrm{~min}$.

\section{Production and Assay of the Enzyme}

Fermentation was carried out according to the modified method of Das and Ghosh (2004). Each of the production medium was inoculated with $10 \mathrm{ml}$ of bacteria inocula in an overnight broth culture of Tryptone soya broth (TSB). It was incubated in rotary shaker at $150 \mathrm{rpm}$ at ambient temperature for 4 days after which the enzyme was extracted every $24 \mathrm{~h}$. The extracted enzyme was clarified with Whatman No 1 filter paper and stored at $4^{\circ} \mathrm{C}$ for further work according to the modified of Correia et al., (2013). The enzyme assay was carried out using CMS assay (Ghose, 1987). The assay was conducted at $50^{\circ} \mathrm{C}$ with a reaction mixture containing $0.5 \mathrm{ml}$ of enzyme and $0.5 \mathrm{ml}$ of $2 \%$ substrate (CMC) dissolved in $0.1 \mathrm{M}$ sodium acetate buffer $(\mathrm{pH} 4)$ and incubated for 30 mins. The reaction was terminated by adding $3 \mathrm{ml}$ of Dinitrosacylic acid (DNS) reagent and heating for 10 mins in a vigorously boiling water bath. The absorbance of the resultant solution was measured at $540 \mathrm{~nm}$ using UV spectrophotometer and glucose concentration was determined from the earlier generated glucose standard curve (Abeer et al.,2014).

\section{Results}

Screening of bacteria for cellulase producing ability

Among the eight bacteria species isolated and screened for cellulase producing potential, four (4) showed positive on screening medium indicated by clear or halo zone around growing microbial colonies, implying that they are efficient cellulase producers as shown in Plate 1 (a-d). They were selected based on the halo zone diameter exhibited (Table 1).

\section{Determination of hydrolysis efficiency}

The calculated hydrolysis efficiency of all the isolates ranged from $40 \%$ to $100 \%$ as tabulated in Table 1. Two isolates exhibited hydrolysis efficiency of between $40-45.4 \%$. The bacteria isolates with the best hydrolysis efficiency $(100 \%)$ was further identified.

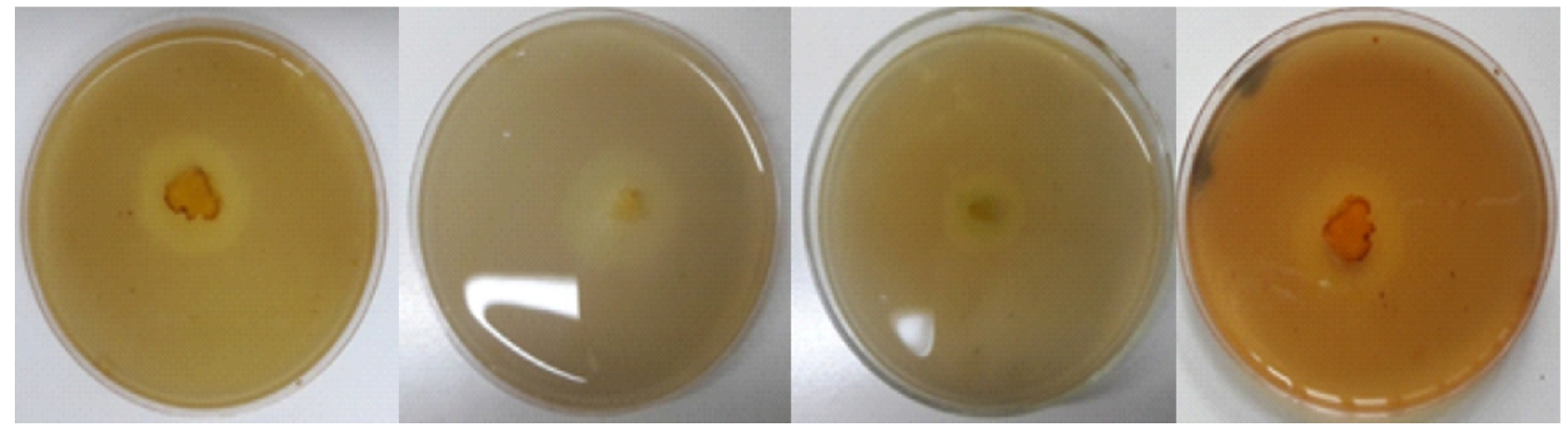

Plate 1: Bacterial isolates (a) Pseudomonas spp. (b) Proteus spp. JC402 (c) Streptomyce spp. (d) Bacillus spp. showing zones of Clearance on cellulase screening medium 
Table 1: Zone of clearance (halo zone) and Hydrolysis efficiency of cellulase enzyme produced by bacteria isolated from saw mill soil

\begin{tabular}{|c|c|c|c|c|}
\hline$S / N$ & Bacteria Isolates & Colony Diameter $\mathrm{C}$ & Halo Diameter & Hydrolysis efficiency \\
\hline & & $(\mathrm{mm})$ & $Z(\mathrm{~mm})^{\circ}$ & Z-C/C (\%) \\
\hline 1. & SM1 (Rod shape) & 27 & - & 0 \\
\hline 2. & SM1 (Rod shape) & 15 & - & 0 \\
\hline 3. & Pseudomonas sp. & 16 & $29 \pm 0.17$ & 81.3 \\
\hline 4. & SM1 (Cooci shape) & 13 & - & 0 \\
\hline 5. & Bacillus sp. & 22 & $32 \pm 0.37$ & 45.4 \\
\hline 6. & SM1 (Rod shape) & 12 & - & 0 \\
\hline 7. & Proteus sp. JC402 & 11 & $22 \pm 0.28$ & 100 \\
\hline 8. & Streptomyces sp. & 15 & $22 \pm 0.19$ & 40 \\
\hline
\end{tabular}

-Means of three replicates \pm Standard deviation

Identification of the PCR amplified 16S rRNA Table 2 shows the distribution of organism identified in the library of $16 \mathrm{~S}$ rRNA isolate based on the analysis by sequence of the PCR product in the non-redundant nucleotide database from
National Center for Biotechnology Information (www.ncbi.nhi.gov) (NCBI) as presented. The isolate with NCBI Accession number LN866654.1 was identified as Proteus spp. JC402.

Table 2. Identity of bacterium isolate by sequence of the $16 \mathrm{~s}$ RNA gene

\begin{tabular}{cccc}
$\begin{array}{c}\text { Isolate } \\
\begin{array}{c}\text { Accession No } \\
\text { NCBI }\end{array}\end{array}$ & $\begin{array}{c}\text { Nucleotide } \\
\text { Number }\end{array}$ & $\begin{array}{c}\text { Reference from } \\
\text { NCBI database }\end{array}$ & Identity \\
\hline $\begin{array}{l}\text { 1.LN866654.1 } \\
\text { whole genome shotgun sequence }\end{array}$ & Proteus Sp. JC402, & $83 \%$ \\
Legend: NCBI: National Centre for Biotechnology Information &
\end{tabular}

Fermentation conditions of cellulase activities using the different biomass

In Fig. (1a), the enzyme activity of PFSB 5\% $(\mathrm{w} / \mathrm{v})$ substrates had the lowest activity of $1.31 \pm$ $0.38 \mathrm{Uml}^{-1}$ while PFSB $7.5 \%(\mathrm{w} / \mathrm{v})$ has the highest activity of $3.2 \pm 0.14 \mathrm{Uml}^{-1}$ at $48 \mathrm{~h}$. The activity

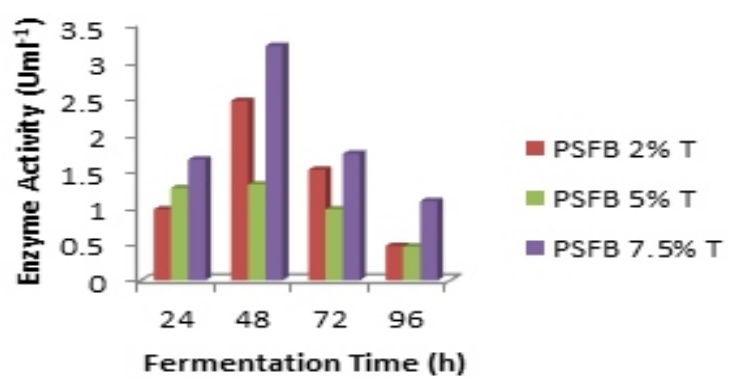

(a) (b) increases till $48 \mathrm{~h}$ in all the treated substrates but decrease thereafter. Whereas in the untreated substrates (Fig. 1b), reverse was the case as the lowest concentration (PFSB $2 \%(w / v)$ ) has the highest activity of $2.76 \pm 0.31 \mathrm{Uml}^{-1}$ and PFSB $7.5 \%(\mathrm{w} / \mathrm{v})$ has the lowest activity of $1.83 \pm 0.23$ $\mathrm{Uml}^{-1}$ at $48 \mathrm{~h}$.

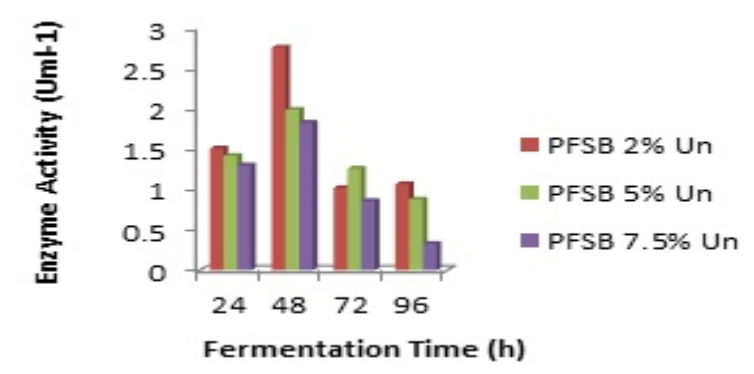

Figure 1: Cellulase Activities of the (a) untreated PFSB and (b) alkaline pretreated PFSB substrates

\section{Discussion}

The selective medium (CMC Agar) consisting of $2 \%$ CMC in NA used for the screening of isolated bacteria for cellulase producing potential relied on the ability of bacteria to hydrolyze cellulose as a sole carbon source (Ramrn et al., 2008). The zone of clearance exhibited by the screened bacteria around their colonies showed appreciable difference in their ability to hydrolyze cellulose with Bacillus spp. and Streptomyces spp. having clearing zone of 16 and $22 \mathrm{~mm}$ respectively. The appreciable difference noticed 
in the zone of clearance exhibited by bacteria isolates used for this present work and the formal (Osho et al., 2017) (data not shown) is an indication that the bacteria species isolated for this work are more efficient cellulase producers. A study on the hydrolysis efficiency of isolated bacteria revealed the bacteria with the best cellulose degrading potential and the largest hydrolysis efficiency was assumed to contain the highest activity. Of the four bacteria isolate selected with $81.3,45.4,40$ and $100 \%$ hydrolysis efficiency respectively, Proteus spp. JC402 exhibited a better hydrolysis efficiency more than the other three, an indication that it has a better cellulase producing potential and can degrade cellulose more efficiently than the rest. Sreedvi and Reddy in (2012) employed this method in the selection of bacteria species with best phytase producing potential.

The progressive increase during the initial days and later decrease in cellulase activity level during fermentation might be due to the elimination of some groups due to the shift in $\mathrm{pH}$ to alkalinity, competition and consequent lack of adequate nutrients and release of toxic substances (Chandrasekaran, 1985). It might also be due to inactivation by microbial proteases secreted out in the system (Zhu et al., 1994) or some other inhibiting substances released by the complex activities of the heterotrophic bacteria during fermentation. The enzyme was seen to exhibit its highest activity at $48 \mathrm{~h}$ for the both substrates. There is scope for exploitation of Proteus spp. JC402 as well as their cellulase for industrial use if scale up studies is conducted to develop an ideal bioprocess.

\section{References}

Abeer, A. E., Zeinat, K., Ali, H., Salwa, A. E. and Mai, A. (2014). Optimization of Aspergillushortai cellulase on poly (Acrylamide-Co-Acrylic Acid) for hydroxylation of cellulose rice straw wastes. Glob. J. Pharmacol. 8(4): 681 - 687.

Abraham, R. E., Verma, M. L., Barrow, C. J. and Puri, M. (2014). Suitability of magnetic nanoparticle immobilized cellulases in enhancing enzymatic saccharification of pretreated hemp biomass. Biotechnol.Biof.7: 90.

Akpan, I. Ikenebomoh, M. J. and Doelle, H. W. (1996). Effect of carbon and Nitrogen Supplements to rice basa-based medium on amylase production by Rhizopus spp. Trop. Sci. $36: 166-173$.

Bhat, M. K. and Bhat, S. (1997). Cellulose degrading enzymes and their potential industrial applications. Biotechnol. Adv.15: 583-20.

Casey, J. P. (1980). Pulp and paper: chemistry and chemical technology, 3rd ed., Wiley Interscience, New York, 1: 152-156, 505 - 597.

Chandrasekaran, M., (1985) Ph.D. Thesis.Cochin University of Science and Technology.

Correia, J. A. C., Junior, J. E. M., Goncalves, I. R. B. and Rocha, M. V. P. (2013). Alkaline hydrogen peroxide pretreatment of cashew apple bagasse for ethanol production: study of parameters. Biores. Technol. 139:249 - 256.

Das, S. and Ghosh, U. (2014). Effect of Nutritional Supplementation of Solid-State Fermentation Medium on Biosynthesis of Phytase from Aspergillus niger NCIM612. J. Sci. Ind. Res., 73: 593 - 597.

Ghose, T.K. (1987). Measurement of cellulase activity. Pur. Appl. Chem. 59: 257 - 268.

Henrissat, B., Teeri, T. and Warren, A. (1998).A scheme for designating enzymes that hydrolyze the polysaccharides in the cell walls of plants. FEBS Lett. 425:352 - 4.

Kumar, G. S., Chandra, M. S., Sumanth, M., Vishnupriya, A., Reddy, B. R. and Choi, Y. L. (2009). Cellulolytic enzymes from submerged fermentation of different substrates by newly isolated Bacillus Spp. FME. J. Kor Soc. Appl. Biol. Chem. 52:17 - 21. 
Lu, W. J. Wang, H. T. Yang, S. J. Wang, Z. C. and Nie, Y. F. (2006). Isolation and characterization of mesophilic cellulose-degrading bacteria from flower stalks-vegetable waste co-composting system. J. Gen. Appl. Microbiol. 51(6): 353 - 360.

Maloney, G. T. (1978). Chemicals from pulp and wood wastes production and applications. Noyes Data Corporation, Park Ridge, New Jersey, pp. 288.

Milala, M. A., Shugaba, A., Gidado, A., Ene, A. C. and Wafar, J. A. (2005). Studies on the use of agricultural wastes for cellulase enzyme production by A. niger. J. Agric. Biol. Sci. 1:325 328.

Miranda, L. M.,Michael, B.,Kam, T.L. and Wensheng, Q. (2011). Characterization of some efficient cellulase producing bacteria isolated from paper mill sludges and organic fertilizers. Int. J. Biochem. Mol. Biol. 2(2): 146 - 154.

Nowak, J., Florek, M., Kwiatek, W., Lekki, J., Chevallier, P. and Zieba E.(2005). Composite structure of wood cells in petrified wood. Mater. Sci. Eng. C25:119-30.

Olanbiwoninu, A. A. and Fasiku, S. (2015). Production of bacterial amylases and cellulases using sweet potato (Ipomoea batatas.(L.) Lam.) peels. Afr. J. Biochem. Res. 9(9): 104 - 109.
Osho, M. B., Nwagala, P. N. and Ojo, E. E. (2017).Production and optimization of bacterial cellulase using agricultural cellulosic biomass by solid state cultivation. Curr.Biotechnol.6: 349 355.

Ramrrn, M., Alimon, A. R., Sijam, K. and Abdullah, N. (2008). Filter paper degradation by bacteria isolated from local termite gut. Res. J. Microbiol. 3(8): 565 - 568.

Reddy, G. P. K., Narasimha, G., Kumar, K.D., Ramanjaneyulu, G., Ramya, A., Kumari, B. S. S. and Reddy, B. R.(2015).Cellulase production by Aspergillus niger on different natural lignocellulosic substrates. Int. J. Curr. Microbiol. App. Sci.4(4): 835 - 845

Saranra, J.P., Stella, D. and Reetha, D. (2012). Microbial cellulases and its applications: A review. Int. J. Biochem. Biotechnol. Sci.1:12.

Sreedevi, S. and Reddy, B. N. (2012). Isolation, screening and optimization of phytase production from newly isolated Bacillus spp.C43.Int. J. Pharm Biol Sci.2(2): 218 - 231.

Zhu, Y., Smit, J. P., Knol, W. and Bol, J. (1994). A Novel Solid-State Fermentation System Using Polyurethane Foam as Inter Carrier. Biotechnol. Lett. 16: 643 - 648. 